\title{
EFFECT OF PRE EMERGENCE HERBICIDES ON WEED CONTROL AND PERFORMANCE OF COWPEA IN SAMARU
}

\author{
Ibrahim Usman ${ }^{1}$
}

\begin{abstract}
Field experiments were carried out in 2010 and 2011 cropping seasons at the Institute for Agricultural Research, Ahmadu Bello University, Zaria- Nigeria located on latitude111', longitude $7^{0} 38^{\prime}$ and $686 \mathrm{~m}$ above sea level in Northern Guinea Savannah Ecological Zone to evaluate the effect of pre emergence herbicides on growth and yield parameters of cowpea. In this study, different pre emergence herbicides were compared for their efficiency on weed control of various weed species under rain-fed conditions in Nigeria. The different herbicides used are, S-metolachlor960EC@ the rate of 3.5 litre ha ${ }^{-1}$, pendimenthaline 33\% (w/v) EC (a) the rate of 3.5 liter $\mathrm{ha}^{-1}$ and Butalachlor E.C at the rate of 3.5Lha- ${ }^{l}$. There was significant yield increase due to Application of pendimenthaline at $3.5 \mathrm{~L} \mathrm{ha-}^{-}+$Hand weeding of cowpea at 6WAS. There was significantly superior performances in terms of plant height, number of leaves per plant, number of branches per plant, number of pods per plant and grain yield hal. However Leaf area per plant and 100 - grain weight were not significantly influenced by the treatments. Of all the weed control methods, chemical weed control using pendimenthaline at 3.5 $\mathrm{L} \mathrm{ha}^{-}+$Hand weeding at $6 \mathrm{WAS}$, significantly gave better results than the other treatments on both growth and yield parameters.
\end{abstract}

Key words: cowpea, herbicides, weed control methods.

\section{INTRODUCTION}

Cowpea (Vigna unguiculata L. Walp) grown in rainy season, is usually infested by quite a number of weed species that compete with the crop right from germination to harvest, affecting the crop yield adversely (Patel et al., 2003). Therefore, in order to enhance crop yield and its effects on soil fertility, control of weeds during this period is very important. The traditional methods of weed control such as hand pulling, hand hoeing and harrowing are very expensive and labour is usually not very available during the peak periods of weed removal from the field (Khan et al., 2000). However, the use of herbicides to control weeds in cowpea grown fields appears to be the only available option (Dadari, 2003). Though most of these herbicides are weed specific, but some to a greater extent, are more effective in controlling weeds than the other traditional ones mentioned above. Weeds are very important in reducing crop yields by lowering input efficiency, serving as hideouts for insect- pests and diseasepathogens, contaminating harvests as debris 
and some exhibiting alleleophatic Properties against crops. Yield losses in cowpea due to weeds were $12.7-60.0 \%$ (Li et al., 2004). The phenomenon involved in crop yield increases as influenced by different weed control methods have already been well described Patel et al., (2003). Muhammad et al., (2003) reported that the presence of weeds in cowpea, reduced yield by $82 \%$ and a significant increase in yield of pods was noted by controlling weeds up to 45 days of sowing. Parasuraman (2000) found that application of pendimenthalin (1.5 - 2.0 $\mathrm{L} \mathrm{ha}^{-1}$ or fluchloralin $\left(1.0-1.5 \mathrm{~L} \mathrm{ha}^{-1}\right)$ at $3 \mathrm{DAP}+$ hand weeding twice at $30 \mathrm{DAP}$ resulted in a significant reduction in weed population, weed dry matter and an increase in cowpea yield under rain-fed conditions. Patel et al., (2003) conducted a field experiment to evaluate weed management strategy for cowpea, a Pre- emergence application of pendimenthalin at $0.75 \mathrm{~kg}$ a. i. $\mathrm{ha}^{-1}+$ weeding at 5 weeks after planting significantly gave higher grain yield of $511 \mathrm{~kg} \mathrm{ha}^{-1}$ and net return of $\left(\$ 4,705 \mathrm{ha}^{-1}\right)$ compared to other treatments. According to Muhammad et al., (2003) the best post- emergence herbicide for the control of weeds in cowpea is phenoxaprop-p-ethyl at the rate of $80 \mathrm{gm} \mathrm{ha}^{-1+}$ glyphosate at 1,800 $\mathrm{gm} \mathrm{ha}^{-1}$ and was observed to be more effective against grasses. Jaibir (2004) reported that pendimenthalin at $1.0 \mathrm{~kg} \mathrm{ha}^{-1}+$ hand weeding at 30 days after planting significantly gave a higher cowpea grain yield, weed density and biomass was lowest in this treatment. The postulation that integrated weed management can be useful to provide better weed control measures should further be assessed. Keeping these facts in view, a comprehensive study should be designed to integrate different weed control methods in rain- fed cowpea crop. This study was therefore designed to evaluate the different pre emergence weed control methods with a view to recommend the appropriate control measure that would give an optimum yield of cowpea with minimal hoe weeding.

\section{MATERIALS AND METHODS}

Two field experiments were conducted under rain- fed conditions for two cropping seasons in 2010 and 2011 respectively; at the Teaching and Research Farm of the Institute for Agricultural Research Ahmadu Bello University, Zaria located on latitude $11^{0} 11^{\text {' }}$ $\mathrm{N}$, longitude $7^{0} 38^{\prime}$ Eand $686 \mathrm{~m}$ above sea level in the Northern Guinea Savannah Ecological Zone of Nigeria. The experiment was laid out in a randomized complete block design (RCBD), consisting of four treatments; the control, S-metolachlor960 EC @ the rate of 3.5 litre $\mathrm{ha}^{-1}$, pendimenthaline $33 \%(\mathrm{w} / \mathrm{v})$ EC @ the rate of 3.5 liter ha ${ }^{-1}$ and Butalachlor E.C at the rate of $3.5 \mathrm{Lha}^{-}{ }^{1}$. Herbicides were applied a day after planting. Spraying was done with a knapsack sprayer fitted with a Tjet nozzle. In addition to the pre emergence control hoe weeding was carried out at 6 WAS for all the treatments. The variety of cowpea used was IAR 48; which was sown on $6^{\text {th }}$ July, 2010 and $11^{\text {th }}$ July, 2011 respectively at three seeds per hole which was later thinned to two seedlings per hole during the first weeding three weeks after planting at inter and intra row spacing of $50 \mathrm{~cm}$ and $25 \mathrm{~cm}$ respectively. All other agronomic practices except those under study were kept normal and uniform for all the treatments. Standard procedures were adopted in recording data for both growth and yield parameters. Species of weed population were counted from one $\mathrm{m}^{2}$ in each plot. The counted weeds were cut from ground surface, stored in containers and brought to the laboratory for biomass assessment. They were dried in the oven until constant weight was achieved. Other parameters recorded included; Plant height $(\mathrm{cm})$, number of leaves per plant, number of branches per plant, leaf area $\left(\mathrm{cm}^{2}\right)$, number of pods per plant, number of seeds per pod, 100 - grain weight (gm) and grain yield $\left(\mathrm{t} \mathrm{ha}^{-1}\right)$. 


\section{RESULTS AND DISCUSSION}

\section{Growth Parameters}

\section{Plant height $(\mathrm{cm})$, number of leaves per plant, number of branches per plant and leaf area $\left(\mathrm{cm}^{2}\right)$}

From Table 01, it could be observed that there was a significant difference among the mean values of treatments due to the different preemergence herbicides used in both 2010 and 2011 cropping seasons at $\mathrm{P}=0.05$. The use of pendimenthaline significantly gave higher mean values on plant height, number of leaves/plant and number of branches/plant at $\mathrm{P}=0.05$ in both seasons. However, the control treatment significantly gave lower mean values at $\mathrm{P}=0.05$ on the same parameters. This observation is in line with the work of Parasuraman (2000) who earlier reported that pre - emergence application of pendimenthalin at $1.5 \mathrm{~L} \mathrm{ha}^{-1}$ or $2.0 \mathrm{Lha}^{-1}$ at $3 \mathrm{DAP}+$ hand weeding at $30 \mathrm{DAP}$, significantly gave higher growth parameters of plant height, number of leaves/plant and number of branches/plant by reducing weed population and weed dry matter in cowpea grown fields. There was no significant difference among the treatments on leaf area. Though pendimenthaline gave higher mean values than the other treatments but they were not significantly different at $\mathrm{P}$ $=0.05$.

\section{Number of pods per plant, pod yield per plot and grain yield hat}

Table 01 show the significant differences in number of pods/plant, number of seeds/pod and grain yield ha-1 in both 2010 and 2011 cropping seasons due to application of different pre emergence herbicides. Pendimenthaline significantly gave higher mean values of number of pods/plant, number of seeds/pod and grain yield ha ${ }^{-1}$ at $\mathrm{P}=0.05$. $100-$ Grain weight was not significantly affected by treatments at $\mathrm{P}=0.05$. The control treatment gave lower mean values, while the use of pendimenthaline gave higher mean values but they were not significantly different at $\mathrm{P}=$ 0.05 . This observation is in line with the work of Patel et al., (2003) who earlier reported that application of pendimenthaline at $3.75 \mathrm{~L}$ ha $^{-1}+$ hand weeding at 5 weeks after sowing significantly gave higher mean values on yield and yield components of cowpea. Also, the net return was estimated to be $(\$ 4,705)$.

\section{Weed density $m^{2}$}

Table 02 shows a significant difference at $\mathrm{P}=$ 0.05 on weed density due to different types of pre emergence herbicides applied. The control treatment significantly gave higher mean values than the rest of the treatments. On the other hand pendimenthaline significantly gave lower mean values of weed density than the rest treatments. This means that a combination of weed control methods involving the chemical control + hand weeding significantly controlled weed population in all plots under this treatment. This observation is in agreement with works of Patel et al., (2003). Who earlier reported that the presence of weeds reduced yield by $82 \%$ and significant yield increase in pod was noted by controlling weeds up to 45 days of sowing. Also, Dadari (2003) earlier reported that the use of herbicides in cowpea to control weeds appears to be useful and considered to be more effective against weeds. 
ڤ్.

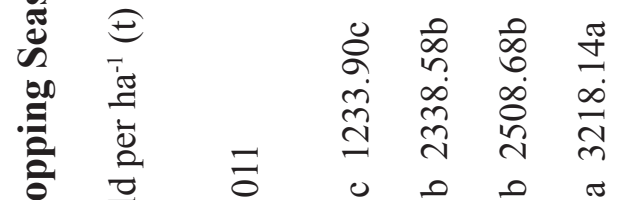

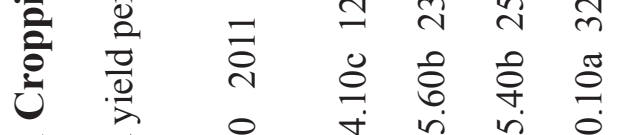

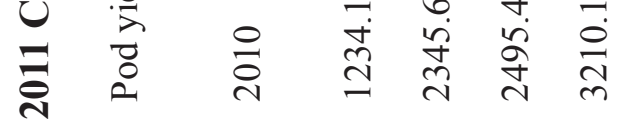

䓂

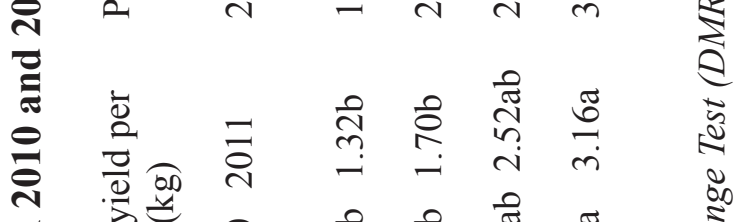

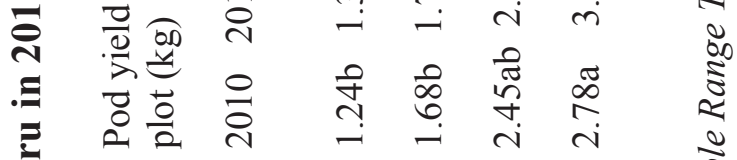

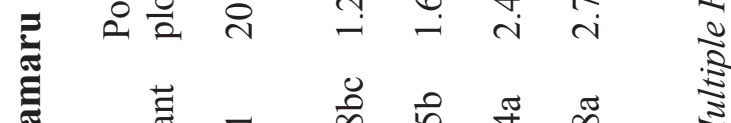

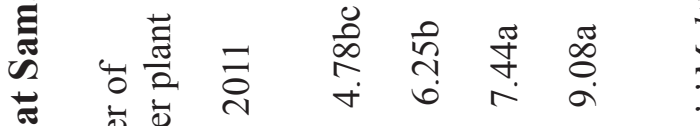

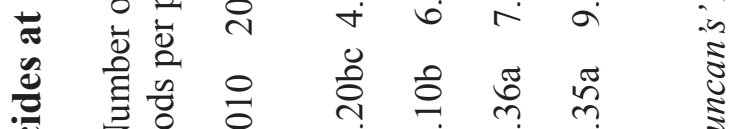

弦

)

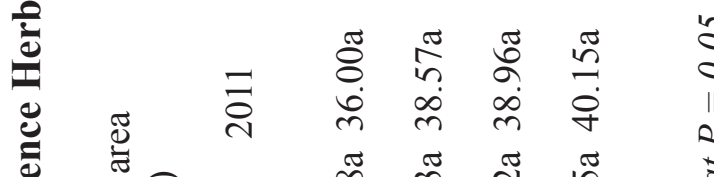

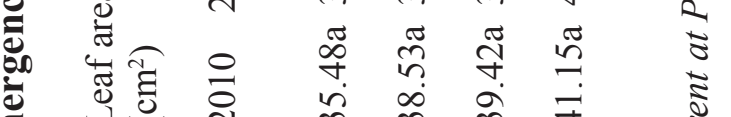

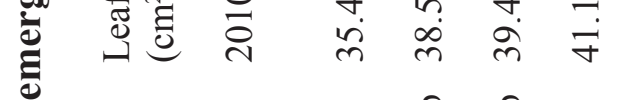

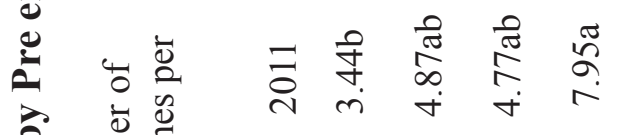

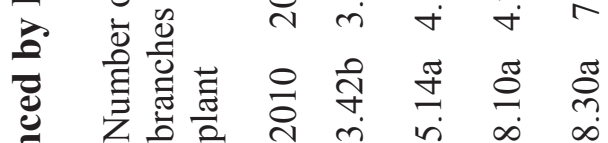

政

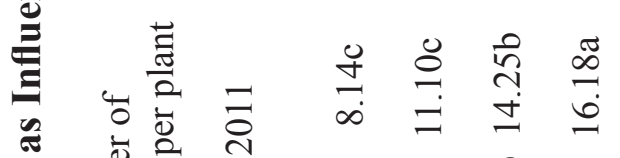

का

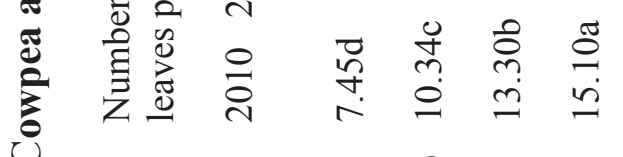

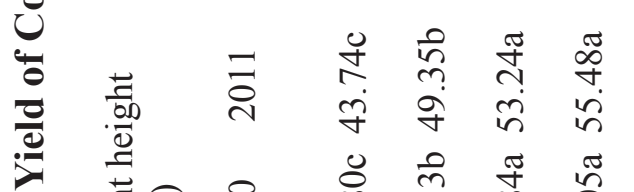

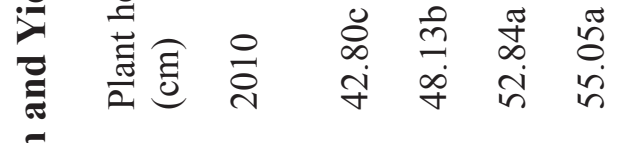

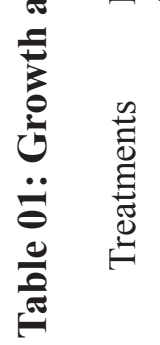

ปั้

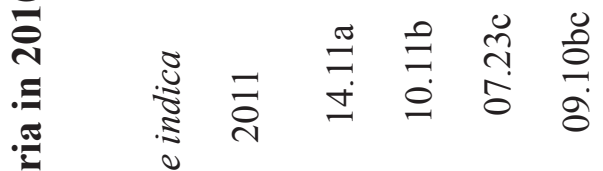

总

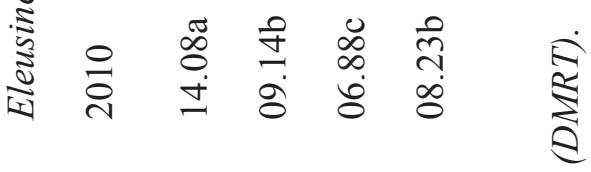

ชั

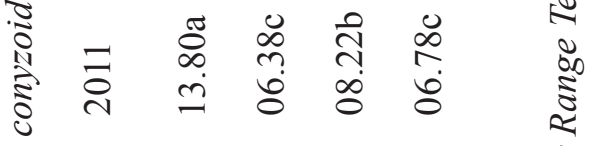

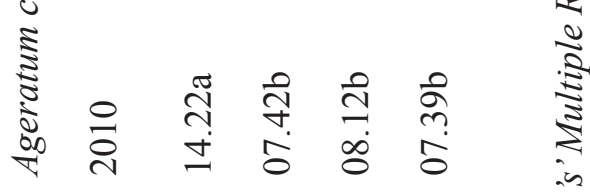

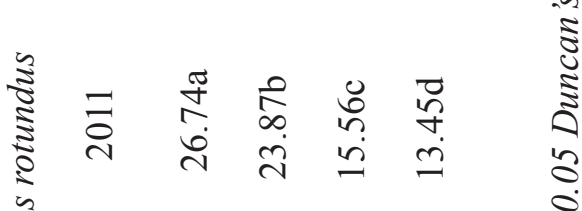

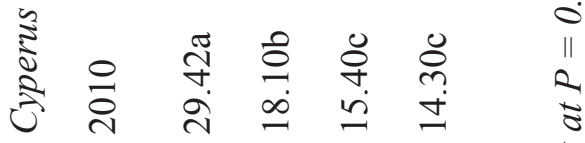

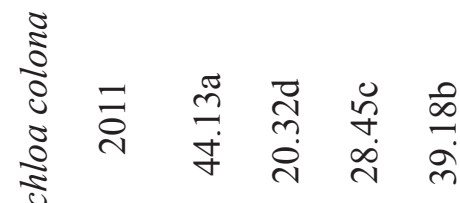

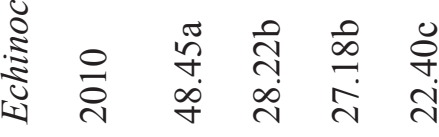

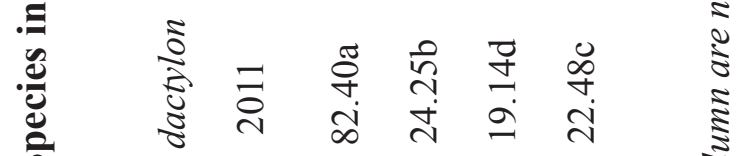

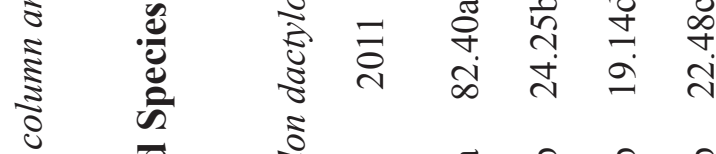

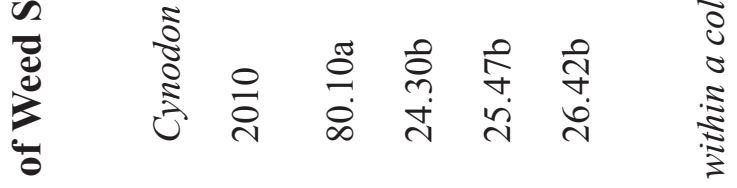

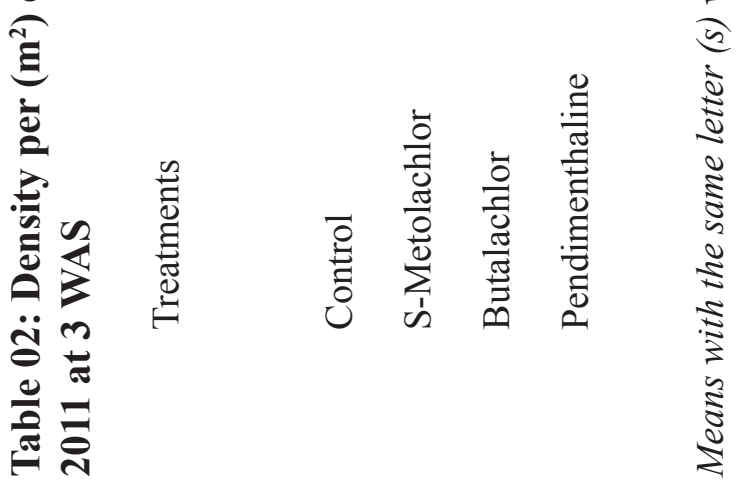




\section{Weed biomass $\left(\mathrm{gm} / \mathrm{m}^{2}\right)$}

Table 03 shows a significant difference on weed biomass among treatment means at $\mathrm{P}=0.05$. The control treatment significantly gave higher weed biomass than the rest treatments, while pendimenthaline significantly gave lower mean values on weed biomass at $\mathrm{P}=0.05$ in all the two cropping seasons. This observation may mean that there was less competition between the crop and weeds since chemical weed control and hand weeding were both employed under this treatment, it succeeded in eliminating most of the weeds there by resulting into a lower competition between the crop and weeds for nutrients, space, light, water and carbon dioxide. However, in the control treatment which had an opportunity for the crop and weeds to compete for nutrients, space, light, water and carbon dioxide gave the weeds the advantage to supersede the crop and utilized resources at its detriment giving the weeds the dominant advantage over cowpea. This resulted in a higher population of weeds in all plots under this treatment over other treatments and hence, higher biomass production in this treatment than the rest. This observation is in agreement with the report of Dadari (2003) that competition between weeds and crop starts right from germination of the crop up to harvest affecting both growth and yield parameters adversely.

\section{CONCLUSION}

The use of pre emergence herbicides significantly gave higher mean values of number of pods/plant, number of seeds/pod and grain yield ha- 1 at $\mathrm{P}=0.05$. as compared to the control. Competition between weeds and crop starts right from germination of the crop up to harvest affecting both growth and yield parameters adversely. It is therefore recommended that farmers should employed the use of pre-emergence for cowpea production. 


\section{REFERENCES}

Dadari S.A. (2003). Evaluation of herbicides in cowpea/cotton mixture in Northern Guinea Savannah. Journal of Sustainable Agriculture and Environment, 5:153 - 159.

Jaibir, T. Singh, H. B. Vivek and Tripathi, S. S. (2004). Integrated weed management in intercropping of mungbean (Vigna radiata) and cowpea fodder (Vigna unguiculata) with pigeonpea (Cajanus cajan) under western U.P. condition. Indian Journal of Weed Science, 36: $133-134$.

Khan, B. M. Asif, M. Hussain, N. and Iqbal, (2000). Agronomic economic impact of different weed control strategies in wheat. J. Res. Sci., 11: $46-49$.

Li, R. Guidong, Yumei, Z. and Zhanzhi, X. (2004). Damage loss and control technology of weeds in cowpea field. Weed Sci., 2: $25-26$.

Muhammad, R. C. Muhammad, J. Tahira, Z. M. (2003). Yield and yield components of cowpea as affected by various weed control methods under rain fed conditions of Pakistan. International Journal of Agriculture and Biology, 09-1-120-124.

Parasuraman, P. (2000). Weed management in rain fed cowpea (Vigna unguiculata) and greengram (Phaseolus radiatus) under North West Agro climatic zone of Tamil Nadu. Indian J. Agrn., 45: 732 - 736.

Patel, M. M. Patel, A. I Patel I. C. Tikka, S. B. S. Henry, A. Kumar, D. and Singh N. B. (2003). Weed control in cowpea under rain fed conditions. In: Proceedings of the National Symposium on Arid Legumes, for Food Nutrition. Security and promotion of Trade Pp : 203 - 206. Hisar, India, 15 - 16 May, 2002. Advances in Arid Legumes Research. 